\title{
ANALISIS FITOKIMIA DAN TOKSISITAS EKSTRAK ETANOL DAUN, KULIT BATANG, AKAR TANAMAN SIMPUR (Dillenia indica L) DENGAN METODE BRINE SHRIMP LETHALITY TEST (BSLT)
}

\begin{abstract}
Phytochemical and Toxicity Analysis of Elephant Apple (Dillenia indica L) Ethanol Extract on Leaves, Bark, and Roots using the Brine Shrimp Lethality Test (BSLT) Method
\end{abstract}

\author{
Marsah Rahmawati Utami *, Ratna Dewi Anjani
}

Universitas Singaperbangsa Karawang

*Koresponden E-mail: marsah.Rahmawati@fikes.unsika.ac.id

DOI: https://doi.org/10.32382/mf.v16i2.1746

\begin{abstract}
The elephant apple (Dillenia indica) is a local plant with medicinal potential. Several studies have stated that its fruit and leaf extracts have pharmacological effects, which includes antioxidant, antimicrobial and antidiabetic activity. This research aims to determine the phytochemical content and toxicity activity of the elephant apple (Dillenia indica L) leaf, bark and root extracts. The method used includes plant determination, phytochemical test, extraction, and toxicity test using the Brine Shrimp Lethality Test (BSLT) method. The data analysis technique for the toxicity test was carried out by determining the $L C_{50}$ value (Lethality Concentration 50) using probit analysis. The results showed that the leaf and stem extracts contained alkaloid, flavonoid, tannin, saponin, terpenoid and steroid class compounds, while the root extract contained alkaloids, flavonoids and tannins. The LC $C_{50}$ extracts of the roots, bark and leaves were 27.10 ppm, 208.26 ppm and 13.57 ppm, respectively. Based on these results, it was concluded that the three extracts have toxicity activity and have the bioactivity potential as an anticancer.
\end{abstract}

Keywords: Dillenia indica, BSLT, LC $C_{50}$, toxicity

\section{ABSTRAK}

Simpur (Dillenia indica) merupakan salah satu tanaman lokal yang berpotensi sebagai obat. Beberapa penelitian menyebutkan bahwa ekstrak buah dan daun simpur, memiliki efek farmakologis diantaranya adalah aktivitas antioksidan, antimikroba dan antidiabetes. Penelitian ini bertujuan untuk mengetahui kandungan fitokimia dan aktivitas toksisitas ekstrak daun, kulit batang, dan akar simpur ( Dillenia indica L ). Metode penelitian yang dilakukan meliputi determinasi tanaman,uji fitokimia, ekstraksi, dan uji toksisitas dengan metode Brine Shrimp Lethality Test(BSLT). Teknik analisis data untuk uji toksisitas dilakukan dengan menentukan nilai $\mathrm{LC}_{50}$ ( Lethality Concentration 50) dengan analisis probit. Hasil penelitian menunjukan bahwa ekstrak daun dan batang mengandung senyawa golongan alkaloid, flavonoid, tannin, saponin, terpenoid dan steroid, sedangkan ekstrak akar mengandung alkaloid, flavonoid dan tannin. $\mathrm{LC}_{50}$ ekstrak akar, kulit batang, dan daun secara berturut-turut adalah 27,10 ppm, 208,26 ppm dan 13,57 ppm. Berdasarkan hasil tersebut dapat disimpulkan bahwa ketiga ekstrak memiliki aktivitas toksisitas dan berpotensi memiliki bioaktivitas sebagai antikanker.

Kata Kunci: Dillenia indica, BSLT, $\mathrm{LC}_{50}$, toksisitas

\section{PENDAHULUAN}

Simpur merupakan salah satu tanaman yang saat ini jumlahnya semakin berkurang sehingga perlu pembudidayaan dan dilestarikan kembali, karena beberapa penelitian menunjukan bahwa simpur memiliki bioaktifitas yang dapat dikembangkan menjadi bahan obat. Secara tradisional daun pohon ini digunakan sebagai pembungkus nasi, buah digunakan untuk obat pencahar dan sakit perut, sebagai minuman pendingin untuk demam dan sebagai campuran obat batuk.. Studi literatur menunjukan simpur mengandung senyawa metabolit sekunder yang memiliki efek farmakologis. Hasil uji fitokimia ekstrak daun simpur mengandung alkaloid, fenol, tanin, flavonoid, steroid, terpenoid, dan saponin (Yoga et al, 2015). Beberapa penelitian yang telah dilakukan, Dillenia indica memiliki efek farmakologis sebagai antioksidan analgesik dan memiliki aktivitas sitotoksik (Das M, et.al, 2012). Buah Dillenia indica memiliki aktivitas antidiabetes dengan menghambat aktivitas enzim 
glukosidase ( Kumar S, et al, 2013). Penelitian yang lain menyatakan bahwa Tanaman Dillenia indica $L$. memiliki efek antifungi dan antiinflamasi (Yeshwante et al, 2009), antimikroba (Apu et al., 2010).Penelitian tentang tanaman simpur asli Indonesia masih sedikit dilakukan dan umumnya penelitian hanya berfokus pada daun dan buah, namun belum ada informasi mengenai kandungan fitokimia akar atau batang dan toksisitasnya. Oleh karena itu perlu dilakukan penelitian analisis fitokimia dan toksisitas mulai dari akar, batang dan daun simpur (Dillenia indica L) sebagai dasar penelitian selanjutnya.

Uji toksisitas dilakukan untuk memaparkan adanya efek toksik atau menilai batas keamanan dalam kaitannya pada penggunaan suatu senyawa. Pengukuran toksisitas dapat ditentukan secara kuantitatif yang menyatakan tingkat keamanan dan tingkat berbahaya zat tersebut. Brine Shrimp Lethality Test (BSLT) merupakan Salah satu metode digunakan untuk uji toksisitas. Metode ini digunakan sebagai skrining awal pencarian senyawa antikanker (Meiny dan Bambang, 2014) dan telah terbukti memiliki korelasi dengan aktivitas antikanker, Selain itu, metode ini juga memiliki kelebihan yaitu praktis, cepat, mudah, murah dan akurat (Purwantini, 2002). Berdasarkan hal tersebut, penelitian ini bertujuan untuk mengkaji aktivitas toksisitas serta kandungan golongan senyawa metabolit sekunder ekstrak daun,kulit batang, dan buah pohon simpur (Dillenia indica L).

\section{METODE}

Desain, Tempat dan Waktu penelitian

Penelitian dilakukan di Laboratorium Fitokimia program Studi Farmasi Universitas Singaperbangsa Karawang pada tahun 2020 dengan desain penelitian eksperimental.

\section{Alat dan Bahan}

Alat-alat yang digunakan adalah seperangkat alat maserasi, neraca analitik, rotavapor, penangas air, alat-alat gelas,mikropipet, botol vial, selang, aerator. Bahan-bahan yang digunakan bagian akar, kulit batang dan daun tanaman simpur (Dillenia indica L), etanol 96\%, telur artemia salina, DMSO, reagen Libermen Buchard, dragendorf, wagner, maeyer, serbuk $\mathrm{Mg}$, garam laut, asam sulfat, asam klorida, asam nitrat, magnesium serbuk, amil alcohol, methanol.

\section{Pengambilan Sampel}

Sampel yang digunakan adalah bagian akar, kulit batang dan daun simpur, diperoleh dari puncak Sempur Karawang, kemudian diidentifikasi di Herbarium Bogoriensis bidang Botani Pusat Penelitian Biologi LIPI Cibinong Jawa Barat.

\section{Pengolahan Sampel}

Bagian tanaman dipisahkan antara bagian kulit batang, daun dan akar. Dicuci bersih dan dikering anginkan. Setelah itu untuk sampel daun dibuat dalam bentuk serbuk dengan ukuran partikel \pm 20 mesh, sedangkan batang dan akar diris tipis-tipis dengan ukuran $\pm 5 \mathrm{~mm}$. Untuk selanjutnya masuk pada tahapan ekstraksi.

\section{Ektraksi}

Serbuk daun, akar dan kulit batang, masing-masing di ekstraksi dengan cara maserasi dengan pelarut etanol 96\%, selama 3 × 24 jam, ekstrak yang diperoleh disaring dengan menggunakan kertas saring kasar dan dipekatkan dengan penguap putar pada suhu $40^{\circ} \mathrm{C}$ kemudian dihitung rendemen masing-masing ekstrak. Ekstrak pekat yang dihasilkan, diuji keberadaan kelompok senyawanya dengan uji fitokimia, meliputi, uji alkaloid, saponin, tanin, flavonoid, terpenoid dan steroid.

\section{Uji toksisitas dengan Brine Shrimp Lethality Test (BSLT) \\ Penetasan telur}

Telur Artemia salina leach dimasukankan pada gelas piala berisi air laut yang diberi aerasi dan penerangan. Kemudian dibiarkan selama 48 jam dengan penerangan. Telur akan menetas dalam 48 jam dan larva siap untuk di uji.

\section{Penyiapan bahan uji}

Ekstrak akar, batang dan daun, masingmasing dilarutkan dalam air laut dan dibuat konsentrasi $2.000 \mathrm{ppm}$ dalam labu takar $5 \mathrm{ml}$, bila ekstrak tidak larut maka ditambahkan beberapa tetes DMSO. Kemudian dibuat larutan 1000 ppm, 800 ppm,400 ppm, 200 ppm, 100 ppm dan 10 ppm dengan cara pengenceran bertahap.

\section{Uji toksisitas}

Pada setiap tiap botol vial dimasukkan 15 ekor larva udang dan $10 \mathrm{ml}$ air laut, yq sudah ditambahkan ekstrak dengan konsentrasi akhir 1000 ppm, 800 ppm,400 ppm, 200 ppm, 100 ppm dan $10 \mathrm{ppm}$. Sebagai kontrol (negatif) digunakan larva udang dengan $10 \mathrm{ml}$ air laut tanpa ekstrak. Kemudian diinkubasi pada suhu kamar selama 24 jam. Dihitung jumlah larva udang yang mati (yang tidak menunjukkan gerakan) atau hidup (terus bergerak). Setiap perlakuan dilakukan sebanyak 3 kali ulangan. $\mathrm{LC}_{50}$ ditentukan dengan membuat kurva hubungan antara log konsentrasi 
ekstrak dengan nilai probit dari \% kematian larva Artemia salina. Apabila pada kontrol ada larva yang mati maka \% kematian larva udang ditentukan dengan rumus Abbot (Meyer et al. 1982).

\% kematian larva : $\quad \frac{\mathrm{T}-\mathrm{K}}{\mathrm{S}} \times 100 \%$

Keterangan : $\mathrm{T}$ : jumlah larva uji yang mati $\mathrm{K}$ : jumlah larva kontrol yang mati $S$ : jumlah larva uji

\section{HASIL}

Sampel penelitian diperoleh di puncak Sempur Karawang dan dideterminasi di Pusat Penelitian Biologi LIPI. Hasil determinasi tanaman simpur menyatakan bahwa jenis spesies tanaman simpur yang digunakan dalam penelitian ini adalah Dillenia indica $L$ dari suku Dileniceae. Bagian akar, kulit batang, daun, diekstraksi dengan cara maserasi dengan pelarut etanol 96\%, maserasi dilakukan dengan $3 \times 24$ jam. Kemudian ekstrak hasil maserasi dilakukan pemekatan dengan rotavorator pada suhu $40^{\circ} \mathrm{C}$. Pada proses ektraksi ini ekstrak daun memberikan rendemen yang terbesar yaitu $21 \%$. Hasil perhitungan rendemen ekstrak dapat dilihat pada Tabel 1 .
Tabel 1 Rendemen ekstrak hasil maserasi

\begin{tabular}{lc}
\hline Ekstrak & Rendemen $(\%)$ \\
\hline Akar & 2,6 \\
Kulit batang & 10,0 \\
Daun & 21,0 \\
\hline
\end{tabular}

Kemudian setelah proses maserasi dan pemekatan, dilakukan uji fitokimia untuk mengetahui golongan metabolit sekunder yang terkandung pada masing-masing ekstrak. Hasil uji fitokimia dapat dilihat pada Tabel 2.

Tabel 2 Hasil uji fitokimia ekstrak akar, batang dan daun

\begin{tabular}{|c|c|c|c|}
\hline \multirow{2}{*}{$\begin{array}{c}\text { Uji } \\
\text { fitokimia }\end{array}$} & \multicolumn{3}{|c|}{ Hasil Pengamatan } \\
\hline & $\begin{array}{l}\text { Ekstrak } \\
\text { akar }\end{array}$ & $\begin{array}{l}\text { Ekstrak } \\
\text { kulit } \\
\text { batang }\end{array}$ & $\begin{array}{l}\text { Ekstrak } \\
\text { daun }\end{array}$ \\
\hline Alkaloid & + & + & + \\
\hline Flavonoid & + & + & + \\
\hline Saponin & - & + & + \\
\hline Tannin & + & + & + \\
\hline Terpenoid & - & + & + \\
\hline Steroid & - & + & + \\
\hline $\begin{array}{l}\text { Ef } \\
\text { engan per } \\
\text { ata penga } \\
\text { kar, kulit } \\
\text { ada Tabel }\end{array}$ & toksik & ekstrak & identifik \\
\hline
\end{tabular}

Tabel 3 Data \% kematian aktivitas toksisitas ekstrak etanol akar, batang dan daun simpur

\begin{tabular}{cccc}
\hline Jenis Ekstrak & $\begin{array}{c}\text { Konsentrasi } \\
(\mathrm{ppm})\end{array}$ & Nilai Probit & \% kematian \\
\hline Akar & 10 & 4,76 & 40 \\
& 100 & 5,2 & 57,8 \\
& 200 & 5,61 & 73,13 \\
& 400 & 5,61 & 73,13 \\
& 800 & 5,71 & 75,8 \\
\hline Kulit batang & 1000 & 5,71 & 75,8 \\
& 10 & 4,75 & 40 \\
& 100 & 4,9 & 46,47 \\
& 200 & 4,97 & 49,13 \\
& 400 & 4,97 & 49,13 \\
& 800 & 5,03 & 51,13 \\
& 1000 & 5,36 & 64,47 \\
\hline Daun & 10 & 4,92 & 46,67 \\
& 100 & 5,31 & 62,27 \\
& 200 & 5,61 & 73,33 \\
& 400 & 5,61 & 73,33 \\
& 800 & 5,61 & 73,33 \\
& 1000 & 5,77 & 77,8 \\
\hline
\end{tabular}


Dari data pengamatan Tabel 3 terlihat bahwa ekstrak daun dan akar memiliki \% kematian larva relatif lebih tinggi dibandingkan ekstrak batang. Data yang diperoleh dianalisis probit dengan menggunakan program Microsoft Excel 2016 untuk mendapatkan nilai Lethality Concentration $\left(\mathrm{LC}_{50}\right)$. $\mathrm{LC}_{50}$ menyatakan jumlah konsentrasi ekstrak yang dapat menyebabkan kematian larva udang sebanyak 50\% selama masa inkubasi 24 jam .Adapun grafik hubungan $\log$ Konsentrasi dan nilai probit yang menyatakan \% kematian Larva ekstrak akar, batang dan daun dapat dilihat pada Gambar 1.

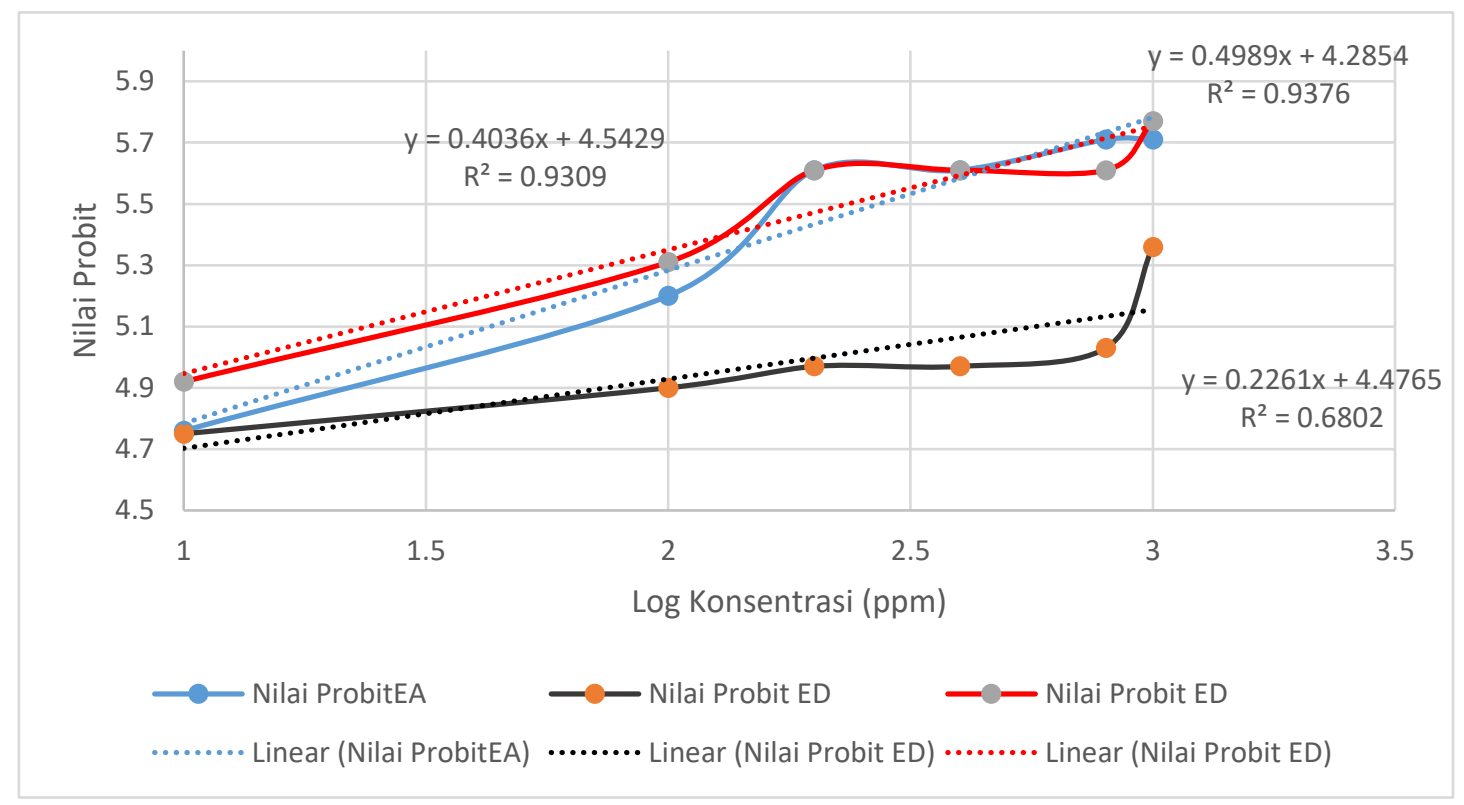

Gambar 1. Plot Log konsentrasi Ekstrak akar (EA), ekstrak batang (EB), ekstrak daun (ED) terhadap nilai probit \% kematian larva udang setelah 24 jam

Nilai $\mathrm{LC}_{50}$ untuk masing-masing ekstrak diperoleh berdasarkan perhitungan metode regresi linear antara log konsentrasi dan nilai probit, Nilai $\mathrm{LC}_{50}$ dapat dilihat pada Tabel 4.

Tabel 4 Nilai LC $_{50}$ ekstrak akar, kulit batang dan daun

\begin{tabular}{cc}
\hline Ekstrak & Nilai $\mathbf{L C}_{\mathbf{5 0}}(\mathbf{p p m})$ \\
\hline Akar & 27,10 \\
Kulit batang & 208,26 \\
Daun & 13,57 \\
& \\
\hline
\end{tabular}

Dari tabel pengamatan terlihat bahwa baik ekstrak etanol akar, batang dan daun memiliki nilai $\mathrm{LC}_{50}$ yang relatif rendah yaitu dibawah 1000 ppm, hal ini menunjukan bahwa ketiga ekstrak ini mempunyai aktivitas toksisitas yang relatif tinggi dan berpotensi sebagai antikanker. Ekstrak etanol daun memiliki Nilai $\mathrm{LC}_{50}$ tertinggi yaitu $13,57 \mathrm{ppm}$.

\section{PEMBAHASAN}

Penelitian ini bertujuan untuk untuk mengkaji aktivitas toksisitas serta kandungan golongan senyawa metabolit sekunder ekstrak daun,kulit batang, dan akar pohon simpur (Dillenia indica L). Sebelum melakukan uji toksisitas dengan metode BSLT ( Brine Shrimp Lethality Test), dilakukan isolasi ekstrak dengan cara maserasi, cara ini merupakan cara sederhana tanpa pemanasan yang dapat digunakan untuk mengekstraksi sampel yang tidak tahan panas maupun yang tahan panas, sehingga dapat menghindari kerusakan komponen senyawa yang tidak tahan panas dan memungkinkan lebih banyak senyawa terekstrak. Maserasi dilakukan dengan pelarut etanol 96\%, Etanol merupakan pelarut universal yang memiliki kemampuan menyari dengan rentang kepolaran yang lebar mulai dari senyawa nonpolar sampai dengan polar (Saifudin et al., 2011). Dari data rendemen yang dihasilkan ekstrak etanol daun memiliki rendemen yang lebih besar hal ini bisa terjadi karena banyaknya jumlah senyawa bioaktif yang terkandung pada ekstrak daun simpur.

Analisis fitokimia dilakukan untuk mengidentifikasi golongan senyawa metabolit sekunder yang terkandung dalam tumbuhan dan umumnya senyawa metabolit sekunder ini berperanan pada aktivitas biologis. Contoh 
senyawa metabolit sekunder golongan polifenol seperti flavonoid dan katekin berpotensi memiliki aktivitas antioksidan yang mampu meredam spesi radikal bebas. Spesi radikal bebas ini merupakan salah satu penyebab terjadinya keruksakan sel DNA yang berimplikasi pada terjadinya penyakit kanker. Dan berdasarkan penelitian Maududi (2009) dikatakan bahwa ekstrak etanol daun simpur memiliki aktivitas antioksidan. Aktivitas antioksidan ekstrak etanol daun simpur ini berkaitan dengan kandungan senyawa metabolit sekunder yang terdapat pada ekstrak. Berdasarkan data hasil penafisan fitokimia pada penelitian ini, menunjukkan bahwa baik ekstrak kulit batang dan daun mengadung senyawa golongan alkaloid, flavonoid, tannin, saponin, terpenoid dan steroid, sedangkan pada ekstrak etanol akar mengandung senyawa golongan alkaloid, flavonoid dan tanin, tidak terdapat golongan saponin, terpenoid dan steroid. Hasil uji

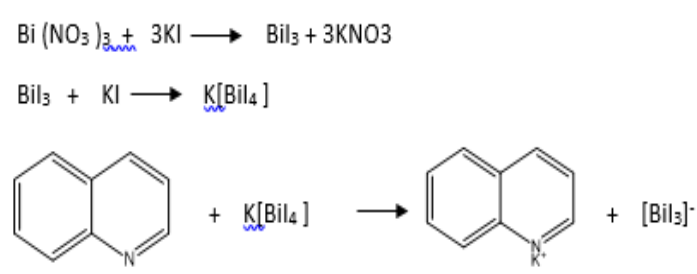

fitokimia ini sejalan dengan penelitian Yoga et al (2015) yang menyatakan bahwa ekstrak daun simpur mengandung alkaloid, fenol, tanin, flavonoid, steroid, terpenoid, dan saponin. Pereaksi yang digunakan untuk Uji alkaloid pada penelitian ini adalah pereaksi Dragendrof dan Meyer, reaksi positif alkaloid dengan pereaksi dragendorff menghasilkan endapan jingga kecoklatan. Pereaksi dragendorff mampu mendeteksi adanya senyawa yang mengandung golongan alkaloid dimana nitrogen pada senyawa alkaloid akan membentuk ikatan kovalen koordinat dengan $\mathrm{K}^{+}$dari Kalium tetraiodobismutat.. Sedangkan uji alkaloid dengan pereaksi Meyer memberikan uji positif endapan kuning, hal ini terjadi karena adanya senyawa alkaloid yang mengandung $\mathrm{N}$ membentuk ikatan kovalen koordinat dengan $\mathrm{K}^{+}$ dari tetraiodomerkurat (II), reaksi pada uji dragendorff dan Meyer dapat dilihat pada Gambar 3 (Parbuntari, 2018).

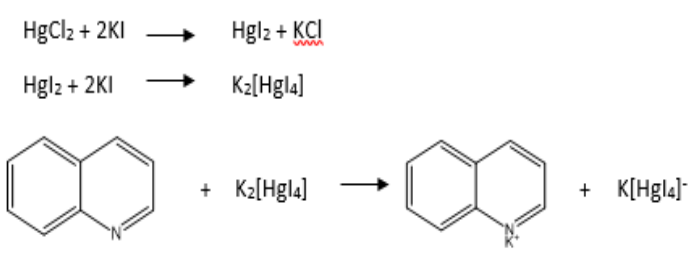

Gambar 2. Reaksi Identifikasi Alkaloid

a. Reaksi uji dragendorff

b. Reaksi uji meyer

Pada uji flavonoid dilakukan dengan Penambahan serbuk magnesium dan $\mathrm{HCl}$, penambahan pereaksi ini menyebabkan terjadinya reaksi reduksi pada senyawa flavonoid yang memberikan warna larutan yang merah, kuning atau jingga (Harborne, 1987). Reaksi yang mungkin terjadi (Parbuntari, 2018) dapat dilihat pada Gambar 4<smiles></smiles><smiles>OC1=C(c2ccc(O)c(O)c2)Oc2cc(O)cc(O)c2C1O</smiles> 
Pada uji terpenoid dan steroid dilakukan dengan metode liberman-buchard, dengan penambahan asam sulfat pekat dan asam asetat anhidrid, memberikan hasil positif dengan larutan<smiles>CC(=O)OC(C)=O</smiles>

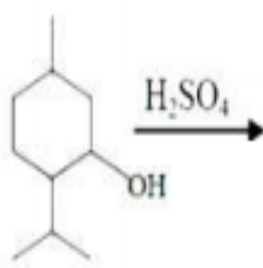

Gambar 4. Reaksi Identifikasi Steroid berwarna jingga kemerahan atau ungu untuk terpenoid dan warna biru untuk steroid, reaksi yang mungkin terjadi pada uji ini ( Parbuntari, 2018) dapat dilihat pada Gambar 4.

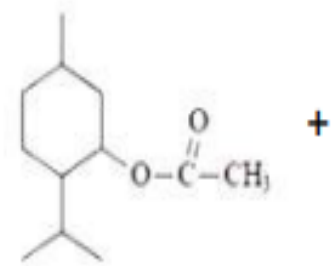

Pembentukan busa pada uji saponin, dapat terjadi karena adanya glikosida yang terikatan dengan saponin yang terhidrolisis dengan adanya air

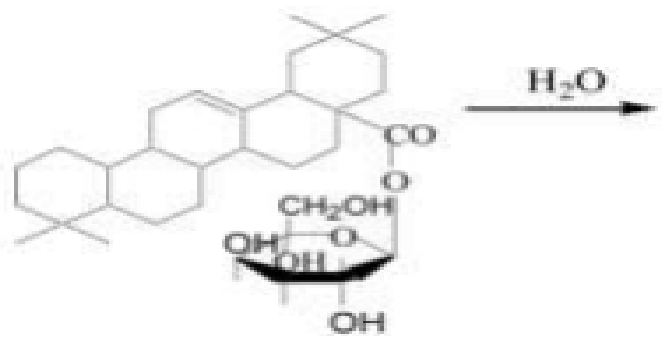

1-Arabinopiriosil-3 $\beta$-asetil oleanoleic Gambar 5. Reaksi Hidrolisis Saponin dalam Air

Aglycone membentuk gula dan senyawa lainya. Kemungkinan reaksi yang terjadi (Parbutari, 2018) dapat dilihat pada Gambar 5.

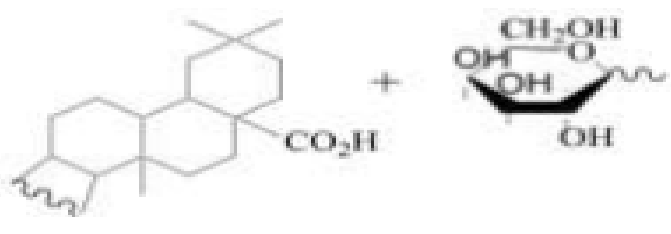

glukosa

2015), pada tahap ini larva udang memiliki kepekaan yang sangat tinggi karena dinding selnya yang masih lunak. Berdasarkan data pengamatan hasil uji toksisitas dengan metode BSLT, diketahui bahwa ketiga ekstrak etanol simpur mempunyai sifat toksik, sifat toksik ini dilihat dari nilai $\mathrm{LC}_{50}$. Nilai $\mathrm{LC}_{50}$ (Letal Consentration) menggambarkan jumlah kadar ekstrak yang menyebabkan kematian dari $50 \%$ Artemia salina, Nilai $\mathrm{LC}_{50}$ ekstrak akar, kulit batang dan daun secara berturut-turut adalah 27,10 ppm, 208,26 ppm dan 13,57 ppm. Menurut Meyer et al (1982) suatu ekstrak dikatakan toksik bila $\mathrm{LC}_{50}<1000$ ppm dan non toksik bila $\mathrm{LC}_{50}>$ 1000 ppm.dari data dapat dikatakan bahwa semua ekstrak simpur bersifat toksik, dan ekstrak daun memiliki ketoksikan yang paling tinggi. Rendahnya nilai $\mathrm{LC}_{50}$ ekstrak bisa terjadi karena perubahan gradien konsentrasi yang drastis antara di dalam dan di luar sel yang menyebabkan senyawa toksik mampu menyebar dengan baik ke tubuh Artemia salina. Efek kerusakan metabolisme yang ditimbulkan terjadi secara cepat dapat dideteksi dalam waktu 24 jam, hingga menyebabkan $50 \%$ kematian Artemia 
salina (Ningdyah, 2015). Rendahnya nilai $\mathrm{LC}_{50}$ terutama pada ekstrak akar dan daun, dapat dijadikan skrining awal bahwa ekstrak memiliki potensi sebagai antikanker, antibakteri, antijamur dan sebagainya.. Sifat toksik pada ketiga ekstrak simpur ini diperkirakan berkaitan dengan kandungan senyawa aktif yang ada didalammya. Namun tingkat kematian Artemia salina ini tidak hanya dipengaruhi kandungan senyawa aktif ekstrak, tetapi juga dipengaruhi besarnya konsentrasi ekstrak. Hubungan konsentrasi ekstrak dan toksisitas dapat dilihat pada grafik hubungan log konsentrasi dan nilai probit. Pada Gambar 1, terlihat bahwa peningkatan konsentrasi menyebabkan peningkatan \% kematian larva Artemia salina.

\section{KESIMPULAN}

Dari uji fitokimia ekstrak daun dan kulit batang, mengandung senyawa golongan alkaloid, flavonoid, tannin, saponin, terpenoid dan steroid, sedangkan pada ekstrak akar mengandung senyawa golongan alkaloid, flavonoid dan tannin. Pada uji toksisitas menggunakan metode BSLT diketahui bahwa ekstrak etanol akar, kulit batang dan daun simpur (Dillenia indica $L$ ) yang bersifat toksik, dengan $\mathrm{LC}_{50}$ secara berturut-turut adalah $27,10 \mathrm{ppm}$, 208,26 ppm dan 13,57 ppm .

\section{SARAN}

Perlu dilakukan penelitian lebih lanjut mengenai bioaktivitas dari ekstrak tanaman simpur serta kandungan senyawa aktifnya.

\section{UCAPAN TERIMA KASIH}

Ucapan terima kasih kepada pihak Simlitabmas dikti atas bantuan dana yang telah diberikan sehingga pelaksanaan penelitian ini berjalan dengan lancar.

\section{DAFTAR PUSTAKA}

Apu AS, Muhit MA, Tareq SM, Pathan AH, Jamaluddin ATM, Ahmed M. 2010. Antimicrobial Activity and Brine Shrimp Lethality Bioassay of the Leaves Extract of Dillenia indica Linn. $J$ Young Pharm Vol 2 No 1.

Jalal P, Salami A,Seydi E. 2015. Role of Oxygen Free Radical in cancer Development and treatment. https://www.intechopen.com/books/fre e-radicals-and-diseases/role-of-oxygenfree-radicals-in-cancer-developmentand-treatment. Diunggah 16 oktober 2020

Kumar S., Kumar V., Prakash O .2011. Enzymes Inhibition and Antidiabetic Effect of
Isolated Constituents From Dillenia indica (L.) leaves extract, Brazilian Journal of pharmaceutical Sciences, 47(2):373-378.

Maududi, A.A. 2009. Produksi Antioksidan dari Daun Simpur (Dillenia indica) Menggunakan Metode Ekstraksi Tekanan Tinggi dengan Sirkulasi Pelarut. Skripsi. Universitas Indonesia.

Meiny S, Bambang C. 2014. Evaluation of Cytotoxicity Effect Hytis Pectinate Poit (Lamiaceae) Extract Using BSLT and MTT Methods. Jurnal sains dan matematika. Vol 22(3) : 84-88.

Mentor R. Hamidi, Blagica Jovanova, Tatjana Kadifkova Panovska. 2014. Toxicological Evaluation of the Plant Products Using Brine Shrimp (Artemia salina L.) model. Macedonian pharmaceutical bulletin, 60 (1) 9-18.

Meyer BN et al. 1982. Brine Shrimp: a Comvenient General Bioassay for Active Plant Constituents. Planta medica 45:31-34

Ningdyah AW, Alimuddin AH, Jayuska A. 2015. Uji Toksisitas dengan Metode BSLT (Brine Shrimp Lethality Test) terhadap Hasil Fraksinasi Ekstrak Kulit Buah Tampoi (Baccaurea macrocarpa). $J K K$, Volume 4(1) 75-83.

Parbuntari H, Prestica Y, Gunawan R, Nurman MN, Adella F. 2018. Preliminary Phytochemical Screening (Qualitative Analysis) of Cacao Leaves (Theobroma Cacao L.) Eksakta Vol. 19 (2).

Purwantini I, Setyowati EP, Hertiani T. 2002. Uji Toksisitas Ekstrak Etanol : Buah, Biji, Daun Makutadewa (Phaleria Macrocarpa (scheff.)boerl.) terhadap Artemia salina Leach dan Profil Kromatografi Lapis Tipis Ekstrak Aktif. Majalah Farmasi Indonesia, 13(2), 101-106.

Saifudin, A., Rahayu, dan Teruna, 2011. Standardisasi Bahan Obat Alam, Graha Ilmu, Yogyakarta.

Vijayraja D\& K. Jeyaprakash, 2019. Phytochemical Analysis, in Vitro Antioxidant Activity and Antiinflammatory Activity of Turbinaria ornata in Human RBC Model. Indian Journal of Geo Marine Sciences Vol. 48 (04), pp. 522-527.

Yeshwante SB, Juvekar AR, Nagmoti DM, Wankhede SS, Shah AS, Pimprikar RB. 2009. Antiinflammatory activity of methanolic extracts of Dillenia indica L. 
leaves. J Young Pharmacist.; 1(1): 636.

Yoga P,Hafrizal R, Inarah F, Nasrullah, Veronika M. H.2015. Skrining
Fitokimia Ekstrak Etanol Daun Simpur (Dillenia indica l.) sebagai Tahapan Awal pada Pengujian Toksisitas. Jurnal Farmasi Kalbar. Vol. 3 No. 1

(c) (1) (2) 